\title{
PENDIDIKAN KEWIRAUSAHAAN DAN EKONOMI KREATIF DI DESA PASANGGRAHAN KECAMATAN PABUARAN KABUPATEN SERANG
}

\author{
Nikke Yusnita Mahardini 1 , Neneng Sri Suprihatin 2 , Kodriyah 3 \\ Program Studi Akuntansi, Universitas Serang Raya \\ 1 nikkeyusnita.m@gmail.com , ${ }^{2}$ neneng.sri.beauty@gmail.com, ${ }^{3}$ kodriyah000@gmail.com
}

\begin{abstract}
Abstrak
Pelaksanaan kegiatan Pengabdian Kepada Masyarakat (PKM) di Desa Pasanggrahan didasari dengan adanya kendala-kendala yang dihadapi masyarakat desa setempat dalam mewujudkan semangat berwirausaha. Beberapa kendala tersebut diantaranya masih minimnya pengetahuan tentang kewirausahaan dan kreatifitas dalam menciptakan inovasi produk. Tujuan pelaksanaan kegiatan PKM adalah mengusulkan alternatif solusi dengan melaksanakan edukasi dan pelatihan kewirausahaan bagi masyarakat desa setempat. Kegiatan ini dilaksanakan melalui tiga tahap, yaitu: (1) tahap persiapan: melakukan observasi dan wawancara, melengkapi dokumen, dan merancang kegiatan; (2) tahap inti: pelaksanaan kegiatan seminar edukasi kewirausahaan dan pelatihan pembuatan produk kewirausahaan. Pelaksana PKM memberikan pelatihan pembuatan pisang mustopa dengan memanfaatkan pisang sebagai bahan utama yang merupakan potensi Desa Pabuaran; (3) tahap akhir: fokus kegiatan pada evaluasi kegiatan dan penyusunan laporan akhir. Ketiga tahap tersebut telah dilaksanakan $100 \%$. Hasil yang diperoleh pada pelaksanaan PKM adalah bertambahnya tingkat pemahaman peserta seminar dan pelatihan tentang kewirausahaan dalam menghasilkan produk yang kreatif dan inovatif melalui pemanfaatan potensi desa.
\end{abstract}

Kata Kunci: kewirausahaan, kreatifitas inovasi, potensi desa.

\begin{abstract}
The implementation of "Pengabdian Kepada Masyarakat (PKM)" in Pasanggrahan Village is based on the constraints faced by the local village community in realizing the entrepreneurial spirit. Some of these obstacles include the lack of knowledge about entrepreneurship and creativity in creating product innovation. The purpose of carrying out PKM activities is to provide alternative solutions by conducting entrepreneurship education and training for local village communities. This activity is carried out through three stages, namely: (1) the preparatory stage: conducting observations and interviews, completing documents, and designing activities; (2) core stage: the implementation of entrepreneurship education seminars and training in making entrepreneurial products. PKM implementers provide training in making mustopa bananas by using bananas as the main ingredient which is the potential of Pabuaran Village; (3) final stage: the focus of activities on the evaluation of activities and preparation of the final report. All three stages have been implemented at $100 \%$. The results obtained in the implementation of PKM are the increasing level of understanding of seminar participants and training on entrepreneurship in producing creative and innovative products through exploiting the potential of the village.
\end{abstract}

Keywords: entrepreneurship, creativity, innovation, village potential. 


\section{PENDAHULUAN}

1. Permasalahan Pengabdian Kepada Masyarakat.

Suatu desa yang memiliki masyarakat yang giat berwirausaha diharapkan akan menggerakkan roda perekonomian desa yang pada akhirnya akan meningkatkan kesejahteraan masyarakatnya. Usaha-usaha menumbuhkan kewirausahaan desa akan lebih tepat jika dikaitkan dengan potensi desa yang ada. Potensi desa merupakan kondisi alam atau keterampilan masyarakat maupun hasil bumi dan sumber daya apapun dari desa yang dapat dijadikan suatu industry desa. Untuk itu perlu usaha untuk mengidentifikasi potensi desa yang dapat dikembangkan sebagai industri desa dan bagaimana usaha komersialisasi dan inovasinya (Widjajani, Fajarwati, \& Retnaningrum, 2015).

Pemanfaatan potensi desa oleh masyarakat dapat dimulai dengan membuat industri kecil rumahan atau homeindustry. Home industry adalah rumah usaha produk barang atau perusahaan kecil. Dikatakan sebagai perusahaan kecil karena seluruh kegiatan ekonomi berpusat dirumah. (Nugraha \& Rahmawati, 2013) mengemukakan bahwa kewirausahaan berbasis home industry atau industri rumahan sangat cocok dengan budaya warga desa pada umumnya, dikarenakan kegiatan tersebut tidak memerlukan segala bentuk aturan formal yang mengharuskan ijazah pendidikan.

Pelaksanaan kegiatan PKM yang bertemakan edukasi kewirausahaan ini diawali dengan melakukan observasi dan wawancara terlebih dahulu. Melalui observasi dan wawancara dengan mitra kegiatan pengabdian, diketahui beberapa permasalahan yang disepakati oleh pihak mitra dan tim pelaksana pengabdian untuk diselesaikan, diantaranya yaitu:

a. Masih minimnya pengetahuan tentang kewirausahaan.

b. Masyarakat kurang termotivasi dalam mewujudkan semangat jiwa kewirausahaan.

(C) Nikke YusnitaMahardini, Neneng Sri

Suprihatin, Kodriyah c. Masih rendahnya tingkat kreatifitas dan inovasi produk dalam memanfaatkan sumber daya yang ada.

d. Potensi desa yang belum dimanfaatkan secara optimal.

Kegiatan ini juga dilatarbelakangi karena rendahnya tingkat pendapatan keluarga yang merupakan hambatan dalam pencapaian kesejahteraan keluarga. Salah satu cara untuk meningkatkan kesejahteraan keluarga adalah dengan membina keluarga menuju tata hidup ekonomis produktif dengan memanfaatkan potensi desa yang ada sehingga menumbuhkan kemampuan berwirausaha keluarg dan memperluas lapangan pekerjaan.

2. Tujuan Pengabdian Kepada Masyarakat.

Berdasarkan masalah yang dihadapi mitra PKM, dapat diketahui bahwa titik berat masalah mitra PKM terletak pada minimnya pengetahuan warga desa akan pentingnya kewirausahaan dan terbatasnya daya kreatifitas dan inovasi dalam rangka mengembangkan bisnis berwirausaha. Berkaitan dengan hal tersebut maka kegiatan PKM ini dilaksanakan dengan tujuan yaitu mengusulkan alternatif solusi dengan melaksanakan edukasi dan pelatihan kewirausahaan bagi masyarakat Desa Pasanggrahan Kecamatan Pabuaran Kabupaten Serang melalui serangkaian kegiatan baik secara toritis maupun secara praktis.

\section{Solusi yang ditawarkan}

Adapun solusi yang ditawarkan dalam kegiatan ini adalah memberikan edukasi tentang kewirausahaan guna membangun semangat jiwa kewirausahaan melalui pemanfaatan potensi desa.

\section{Kajian teoritik}

\section{PendidikanKewirausahaan}

Kewirausahaan sejatinya merupakan suatu proses penerapan kreativitas dan inovasi dalam memecahkan persoalan serta peluang untuk memperbaiki kehidupan (usaha) (Marwati \& 
Astuti, 2012).Kegiatan kewirausahaan mengarah pada upaya mencari, menciptakan dan menerapkan cara kerja, teknologi dan produk baru secara efisiensi guna memberikan pelayanan yang lebih baik atau memperoleh keuntungan yang lebih besar.

(Kartika, 2013) menjelaskan bahwa wirausaha adalah orang-orang yang memiliki jiwa kreatif dan inovatif yang tinggi dalam hidupnya, dengan jalan mengembangkan ide dan meramu sumberdaya untuk menemukan peluang (opportunity) dan perbaikan (preparation) hidup. Menurut (Sukidjo \& Muhson, 2012) ada beberapa hal yang mencerminkan kewirausahaan diantaranya: percaya diri, focus pada tujuan dan hasil, keberanian mengambil risiko, kepemimpinan, bersifat visioner, kreatif dan inovatif.

Pendidikan kewirausahaan dalam pengabdian ini adalah segala sesuatu yang dilakukan secara sadar oleh masyarakat desa dalam membentuk jiwa dan semangat wirausaha guna meningkatkan perekonomian desa melalui ekonomi kreatif.

\section{Pemberdayaan Ekonomi Desa}

Dalam pemberdayaan masyarakat, maka masyarakatlah yang menjadi aktor dan penentu pembangunan. Dalam kaitan ini, usulan-usulan masyarakat merupakan dasar bagi program pembangunan lokal, regional, bahkan menjadi titik pijak bagi program nasional. Masyarakat juga menemu-kenali solusi yang tepat dan mengakses sumber daya yang diperlukan, baik sumber daya eksternal maupun sumber daya milik masyarakat itu sendiri. Salah satu strategi yang memungkinkan dalam pemberdayaan masyarakat adalah pengembangan ekonomi yang berbasis kreatifitas. Disini masyarakat akan difasilitasi untuk mengkaji kebutuhan, masalah dan peluang kelanjutan mutu kehidupan mereka sendiri.

Pemberdayaan pada hakikatnya adalah untuk menyiapkan masyarakat agar mereka mampu dan mau seacara aktif berpartisipasi dalam setiap program dan kegiatan pembangunan yang

(C) Nikke YusnitaMahardini, Neneng Sri

Suprihatin, Kodriyah bertujuan untuk memperbaiki mutu hidup (kesejahteraan), baik dalam pengertian ekonomi, sosial, budaya, fisik, ataupun mental.

\section{Pemberdayaaan Masyarakat Desa melalui Ekonomi Kreatif}

Kemunculan ekonomi kreatif adalah efek dari pergerakan ekonomi global yang melaju semakin pesat, kemudian ekonomi kreatif dapat berkembang ke daerah-daerah. Kemunculan ekonomi kreatif dilatari oleh beberapa sisi, diantaranya: (a) konsumen, menginginkan daripada variasi yang dibutuhkan begitu banyak dan penyebaran secara cepat menuntut untuk selaluberinovasi; (b) keterbatasaninformasi.

Saat ini paradigma baru telah lahir akibat perkembangan kehidupan dunia ekonomi dan bisnis, yaitu dari ekonomi berbasis sumber daya bergeser ke paradigma ekonomi kreatif. Era globalisasi saat ini banyak memberikan dampak terhadap perkembangan berbagai sektor dari teknologi hingga ekonomi. Perkembangan teknologi dan informasi ini melahirkan pola kerja, produksi, distribusi yang lebih murah dan efisien.

\section{Jenis-Jenis Ekonomi Kreatif}

(Sholihin, Arianto, \& Khasanah, 2018) mengemukakan bahw ekonomi kreatif merupakan sebuah konsep di era ekonomi baru yang mengintensifka ninformasi dan kreatifitas dengan engandalkan ide dan pengetahuan dari sumber daya manusia sebagai factor produksi yang pertama.

Jenis-jenis kegiatan ekonomi yang termasuk dalam ekonomi kreatif yang tertuang dalam Intruksi Presiden Nomor 6 Tahun 2009, yaitu: (1) periklanan; (2) arsitektur; (3) pasar seni dan barang antik; (4) kerajinan; (5) desain; (6) fashion (mode); (7) film,video, dan fotografi; (8) permainan interaktif; (9) musik; (10) seni pertunjukkan; (11) penerbitan dan percetakan; (12) layanan komputer dan piranti lunak; (13) radio dan televisi; (14) riset dan pengembangan serta (15) kuliner (Shofa \& Nugroho, 2018).

25 | Ka ibon A b hin a y 


\section{Manfaat dan Tujuan Ekonomi Kreatif}

Bukan lagi penafian jika adanya suatu program tanpa tujuan dan keuntungan yang ingin dicapai. Istilah ekonomi kreatif bukan karena tibatiba dan sia-sia melainkan dipikirkan dan direncanakan dengan kesungguhan serta adanya hal-hal yang ingin diraih, seperti: mengurangi tingkat pengangguran dan kemiskinan, memberikan kontribusi income, terciptanya iklim bisnis ositif, terbangunnya citra dan identitas bangsa, terperhatikannya sumberdaya, terciptanya kreatifitas dan inovasi

\section{Hasil dan manfaat yang diharapkan.}

Hasil dan manfaat yang diharapkan dalam kegiatan PKM ini adalah semakin bertambahnya tingkatp emahaman peserta seminar dan pelatihan tentang kewirausahaan dalam menghasilkan produk yang kreatif dan inovatif melalui pemanfaatan potensi desa.

\section{METODE PELAKSANAAN}

1. Sasaran Pengabdian Kepada Masyarakat

Pada kegiatan pengabdian ini tim pelaksana menentukan terlebih dahulu khalayak sasaran. Khalayak sasaran pengabdian masyarakat ini adalah penduduk Desa Pasanggarahan dengan sasaran utama para remaja dan ibu rumah tangga.

Warga desa memiliki sebuah perkumpulan yang digunakan sebagai wadah diskusi dan saling menyebarkan informasi. Melalui perkumpulan tersebut diharapkan wawasan dan keterampilan dalam berwirausaha akan dapat menyebar lebih luas kepada warga lainnya yang tidak dapat hadir pada pelaksaan penyuluhan dan pelatihan kewiraushaan.

2. Tahapan Pelaksanaan Pengabdian Kepada Masyarakat.

Pelaksanaan kegiatan dilakukan melalui beberapa tahapan, yaitu:

A. TahapAwal.

(c) Nikke YusnitaMahardini, Neneng Sri

Suprihatin, Kodriyah
Tahap awal merupakan tahap persiapan. Kegiatan yang dilaksanakan pada tahap ini adalah: (1) observasi dan wawancara. Tahap ini dilakukan dengan tujuan untuk mengamati dan meninjau secara langsung kondisi yang ada dilapangan. Observasi dan wawancara dilakukan sebagai analisis awal untuk mendapat informasi mendalam dan menyeluruh mengenai permasalahan mitra dan mencari solusi yang dibutuhkan dan tepat sasaran. Wawancara yang dilakukan yaitu dengan bertemu secara pribadi dengan informan dan mengajukan pertanyaan yang diperlukan mengenai masalah penyelidikan. Metode wawancara memiliki keunggulan diantaranya informasi dapat dikumpulkan dari orang-orang yang kurang mampu dalam membaca, data yang dikumpulkan sangat dapat diandalkan karena pewawancara mengumpulkan data secara langsung (Gumanti, Moeljadi, \& Utami, 2018); (b) kelengkapan administrasi dilakukan sebagai prosedur formal untuk melegalkan kegiatan pengabdian; (c) merancang kegiatan inti dan menentukan materi dan bahan pelatihan yang sesuai dengan kondisi kebutuhan mitra dan sebagai solusi dari permasalahan yang dihadapi. B. Tahap Inti.

Tahap inti merupakan tahap pelaksanaan. Dalam tahap inti, fokus kegiatan pengabdian dilakukan yaitu pendampingan dan bimbingan kepada mitra melalui serangkaian model pembelajaran seminar dan pelatihan. Pada tahap ini secara garis besar terdiri dari dua jenis kegiatan, yaitu: (1) seminar edukasi kewirausahaan; dan (2) pelatihan pembuatan produk. Pelatihan pembuatan produk yang dipilih adalah dengan memanfaatkan potensi desa dari sector perkebunan.

C. TahapAkhir

Kegiatan yang dilaksanakan pada tahap akhir yaitu: (1) evaluasi dari keseluruhan serangkaian kegiatan; (2) penyusunan laporan akhir. 


\section{HASIL DAN PEMBAHASAN}

Hasil yang dicapai dalam kegaiatan ini adalah sebagai berikut:

\section{A. Tahap Awal}

Fokus kegiatan dalam tahap awal yaitu: (1) melakukan observasi dan wawancara. Observasi dan wawancara dilakukan dengan tujuan mengamati dan meninjau secara langsung kondisi yang ada dilapangan. Melalui observasi tim pengabdian masyarakat dapat melihat secara langsung lokasi dan situasi mitra pengabdian di Desa Pasanggrahan. Sementara itu, wawancara dilakukan dengan kepala desa setempat dan beberapa warga desa dimaksudkan untuk menggali informasi tentang potensi desa dan permasalahan yang ada. Dari hasil observasi dan wawancara diketahui permasalahan yang dihadapi oleh mitra, yang kemudian tim pelaksana PKM mencari solusi yang sesuai dan tepat sasaran; (2) kelengkapan administrasi yang meliputi dokumen-dokumen yang perlukan sebagai bukti legalitas dalam pelaksanaan PKM; (3) merancang kegiatan inti dan menentukan materi dan bahan pelatihan. Pertimbangan dalam menentukan bahan atau materi pada kegiatan pelatihan kewirausahaan adalah berdasarkan dari sumber daya yang dimiliki desa setempat. Pelaksanaan kegiatan pada tahap awal telah $100 \%$. Hasil yang diperoleh dari tahap ini yaitu: (1) jadwal serangkaian kegiatan pengabdian dari mulai tahap awal, tahap inti sampai dengan tahap akhir; (2) materi yang akan digunakan sebagai bahan edukasi kewirausahaan; (3) menentukan khalayak sasaran kegiatan pengabdian.

\section{B. TahapInti}

Padatahapinifokusutama kegiatan pengabdian yaitu pendampingan dan bimbingan kepada mitra melalui serangkaian model pembelajaran seminar dan pelatihan. Model pembelajarandenganmetode seminar dipilihkarenamemilikibeberapakeunggulan,

(C) Nikke YusnitaMahardini, Neneng Sri

Suprihatin, Kodriyah diantaranya: dapatmembangkitkanpolapikir yang logis, teknik dan prosedur dapat diaplikasikan pada berbagai jenis problema, menstimulus dan meningkatkan keterampilan dalam memahami problema, mendorong peserta seminar untuk menganalisa secara menyeluruh, memunculkan daya konsentrasi yang tinggi pada diri peserta.

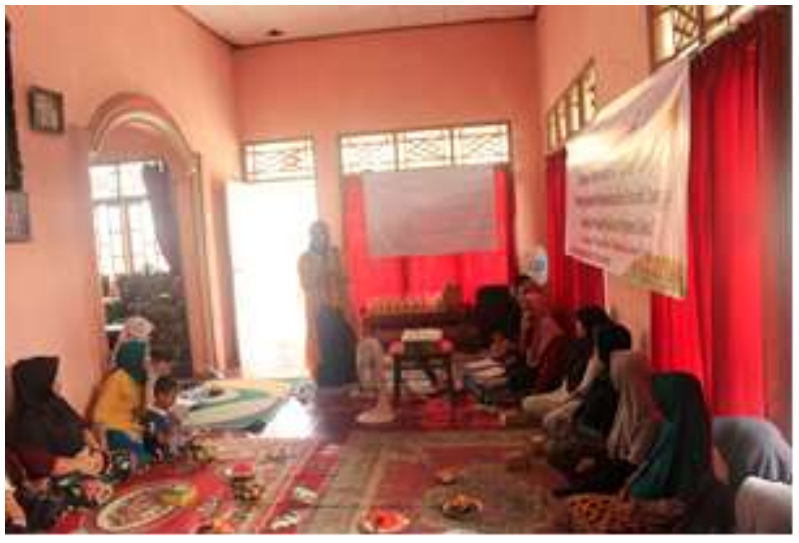

Gambar 1.

Kegiatan Seminar Edukasi Kewirausahaan

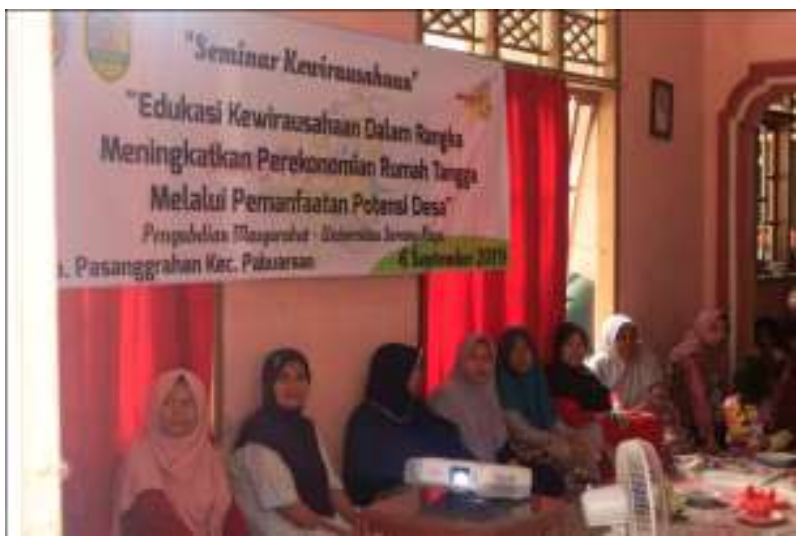

Gambar 2.

Peserta Seminar Edukasi Kewirausahaan

Kegiatan berikutnya adalah diadakannya pelatihan pembuatan produk makanan ringan dengan memanfaatkan potensi desa dari sector perkebunan yaitu pisang. Pertimbangan ini dipilih karena ketersediaan bahan baku yang mudah didapat yang merupakan hasil desa setempat. Tim pelaksana PKM memberikan alternative solusi dalam mengkreasikan makanan ringan berbahan dasar pisang menjadi pisang mustopa. Dengan 
varian dan cita rasa yang berbeda, olahan makanan ringan berbahan dasar pisang memiliki nilai jual yang lebih, dan dapat dimanfaatkan sebagai peluang usaha dalam rangka meningkatkan perekonomian rumah tangga.

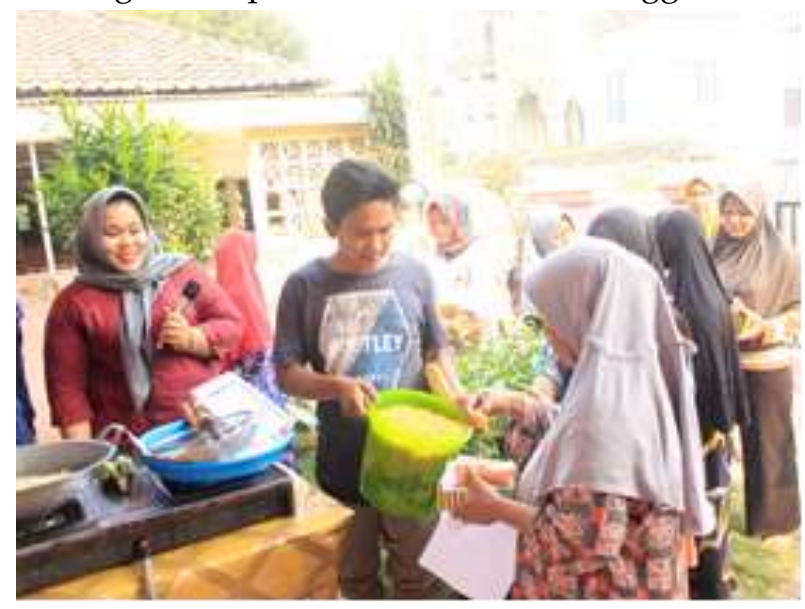

Gambar 3.

Pelatihan Pembuatan Produk Kewirausahaan

Agenda utama dalam tahap ini yaitu seminar edukasi kewirausahaan dan pelatihan pembuatan produk makanan ringan dan pengemasan produk dilaksanakan pada tanggal 6 September 2019. Serangkaian kegiatan seminar dan pelatihan dalam tahap inti telah dilaksanakan dengan baik, yang artinya kegiatan PKM pada tahap inti telah mencapai $100 \%$. Hasil yang diperoleh pada tahap inti adalah bertambahnya tingkat pemahaman peserta seminar dan pelatihan tentang kewirausahaan, dimana peserta yang hadir terdiri dari para remaja dan ibu rumah tangga.

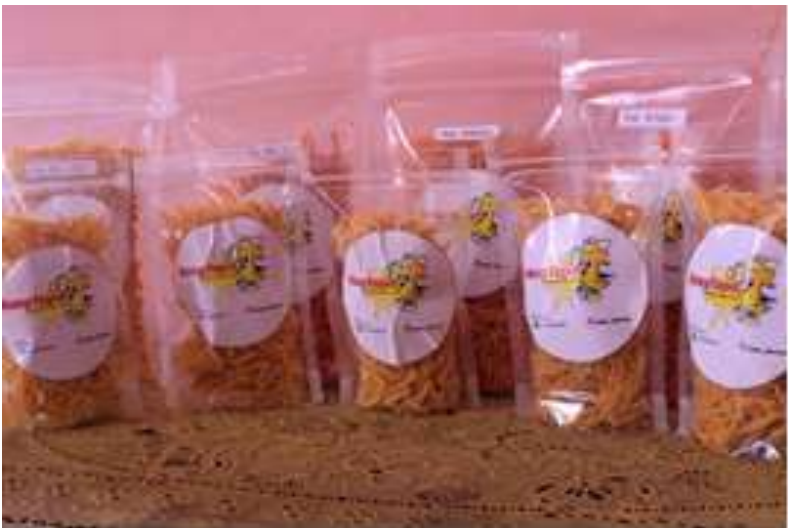

(c) Nikke YusnitaMahardini, Neneng Sri

Suprihatin, Kodriyah
Gambar 4.

Contoh Produk Kewirausahaan Pisang Mustopa

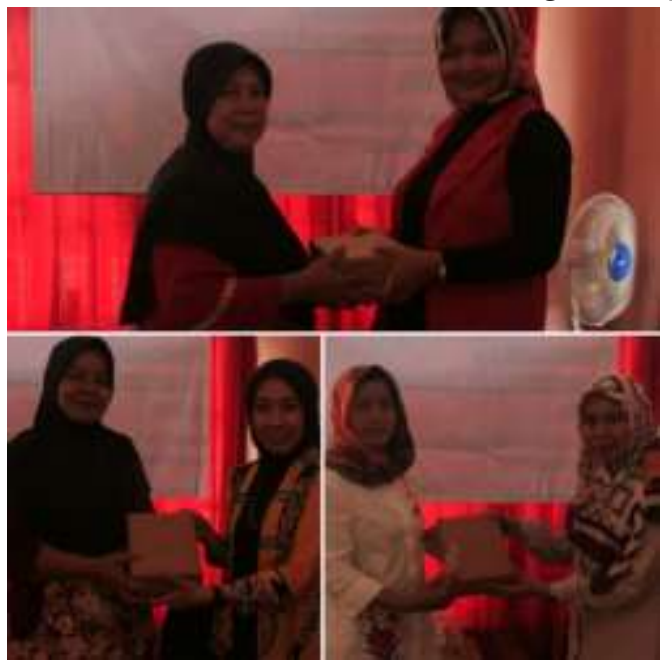

Gambar 5.

Penyerahan Hadiah Doorprize Kepada Peserta Seminar

C. TahapAkhir

Pelaksanaan tahap akhir yaitu dengan melakukan hasil evaluasi pada seluruh rangkaian kegiatan PKM dan penyusunan laporan akhir. Pada tahap ini diketahui hasil bahwa setelah pelaksanaan seminar dan pelatihan kewirausahaan, masyarakat Desa Pasanggrahan memiliki wawasan dan semangat kewirausahaan, serta semakin meningkatnya kreatifitas dan inovasi warga dalam membangun usaha bisnis umah angga (home industry). Selanjutnya, hasil akhir sebagai wujud pertanggungjawaban pelaksanaan kegiatan PKM adalah laporan kegiatan.

\section{KESIMPULAN DAN SARAN}

Kesimpulan

Beberapa hal yang dapat disimpulkan dari keseluruhan hasil kegiatan kemitraan ini antara lain:

a. Program pengabdian kepada masyarakat secara keseluruhan telah berjalan 100\%, artinya semua tahap kegiatan kemitraan telah dilakukan dengan sabaik-baiknya dan penuh tanggung jawab mulai dari tahap inti sampai dengan tahap akhir.

b. Setelah mengikuti seminar dan pelatihan kewirausahaan, masyarakat Desa Panggrahan lebih memiliki wawasan dan semangat kewirausahaan.

28 | Ka ibon A b hin a y 
Saran

Beberapa hal yang dapat disarankan dari kegiatan ini adalah:

a. Kegiatan seminar dan pelatihan kewirausahaan ini mendapatkan respon positif dari masyarakat desa setempat, sehingga diharapkan praktik kewirausahaan terus berjalan secara berkelanjutan.

b. Diharapkan dapat mengembangkan kegiatan ini dengan cakupan wilayah yang lebih luas.

c. Diharapkan warga masyarakat desa memiliki wadah sebagai tempat untuk memasarkan barang dagangan sebagai pelakasanaan kegiatan wirausaha dalam rangka mewujudkan masyarakat yang mandiri.

\section{DAFTAR REFERENSI}

Gumanti, T. A., Moeljadi, \& Utami. (2018). Metode Penelitian Keuangan. Jakarta: Mitra Wacana Media.

Kartika, R. S. (2013). Peluang Mengembangkan Kewirausahaan Desa Berbasis Potensi Desa (Studi Deskriptif di Desa Karang Rejo Kecamatan Negeri Katon Kabupaten Pesawaran, Kampung Suka Jawa Kecamatan Bumi Ratu Kabupaten Lampung Tengah dan Desa Sidoasri Kecamatan Candi Puro Kabupate. Jurnal Bina Praja, 05(04), 281-300.

Marwati, S., \& Astuti, I. D. (2012). Model Pemberdayaan Perempuan Miskin Melalui Pengembangan Kewirausahaan Keluarga Menuju Ekonomi Kreatif Di Kabupaten Karanganyar. SEPA, 9(1), 134-144.

Nugraha, S. P., \& Rahmawati, C. (2013). Maksimalisasi Potensi Peningkatan Pendapatan Rumah Tangga melalui Pengenalan Home Industri pada Kaum Perempuan di Desa. Jurnal Inovasi Dan Kewirausahaan, 2(3), 173-177.

Shofa, I., \& Nugroho, D. (2018). Pertumbuhan dan Strategi Pengembangan Ekonomi Kreatif Kota Malang. Jurnal Pangripta, 1(1), 75-85.

Sholihin, M. R., Arianto, W., \& Khasanah, D. F. (2018). Keunggulan Sosial Media Dalam Perkembangan Ekonomi Kreatif Era Digital Di Indonesia. Prosiding 4th Seminar Nasional Dan Call for Papers, 149-160.

Sukidjo, \& Muhson, A. (2012). Model Pemberdayaan Kelembagaan Lokal sebagai Wahana Pendidikan Pengembangan Usaha.

(C) Nikke YusnitaMahardini, Neneng Sri

Suprihatin, Kodriyah
Cakrawala Pendidikan, Jurnal Ilmiah Pendidikan,31(3), 1-18.

Widjajani, Fajarwati, A., \& Retnaningrum, E. (2015). Model Sistem Pembangunan Kewirausahaan Desa sebagai Sarana untuk Meningkatkan Kesejahteraan Masyarakat Desa. Sosiohumanitas, XVII(2), 110-129. 